\title{
Research on the border trade between Yunnan and Myanmar
}

\author{
Xu Yanqiu* \\ International Business School \\ Yunnan University of Finance and Economics \\ Kunming, China \\ 517801485@qq.com
}

\author{
Zhang Lili \\ International Business School \\ Yunnan University of Finance and Economics \\ Kunming, China \\ 419444190@qq.com
}

\begin{abstract}
Ruili, the trial area of Yunnan-Burmese border economic and Trade, the opening of the southwest important international port, international cultural exchange window, This paper has manifested a disjunction in making policy and the need of business, the way of border trade settlement, unreasonable of border trade settlement, Yunnan-Burma trade policy imperfections. This paper is intended to manifest better service in Yunnan and Burma, so that enterprises and people all enjoy the prospering frontier and enriching people.
\end{abstract}

Keywords-FDI; GDP; Yunnan province

\section{INTRODUCTION}

In the context of economic globalization, regional economic integration has become a development trend of contemporary economics.in the recent, RMB has become a basket of currencies, so it will speed up the process of internationalization of the RMB, make border trade more freely.This paper mainly describe the course of economic and trade development between Yunnan and Myanmar.and then this paper analyze the constraints currently. Finally, we give some advice to the government based on our analysis.

\section{The Status AND ANALYSis of the DeVElopment of BORDER TRADE IN YUNNAN AND MYANMAR}

\section{A. The advantage of Yunnan and Myanmar border trade}

Yunnan Province has a reputation of "Kingdom of nonferrous metals". The advantages of resources are Variety of metal mineral.Myanmar has abundant oil, natural gas, agriculture, timber, stone and other resources; and electricity, mineral and tobacco are the pillar industry of Yunnan Province, through years of technical renovation and transformation, power has been changed greatly, mineral resources development has changed from a single primary products to high value-added products are.

As shown in Table 1, Currently, Yunnan and Myanmar, the two sides not only have highly complementary in economic and trade structures, but also in natural resource endowments. Thus,large market advantage, favorable policy support, will make Yunnan and Myanmar achieve common development goals through the complementary advantages. on the one hand, Import and export of goods can promote the development of trade in goods through the complementary advantages, and accelerated the development and deepened of bilateral economic level of Yunnan and Myanmar Trade and Economy.

TABLE I. EXPORT OF ALL KINDS OF PRODUCTS IN BURMA

(USD Million )

\begin{tabular}{|c|c|c|c|}
\hline type & $\mathbf{2 0 1 2 - 2 0 1 3}$ & $\mathbf{2 0 1 1 - 2 0 1 2}$ & Increase/decrease \\
\hline $\begin{array}{c}\text { livestock } \\
\text { products }\end{array}$ & 1394.251 & 1432.936 & -38.240 \\
\hline $\begin{array}{c}\text { aquatic } \\
\text { product }\end{array}$ & 32.908 & 41.201 & -8.293 \\
\hline Minerals & 358.632 & 310.393 & 83.110 \\
\hline $\begin{array}{c}\text { Forest } \\
\text { product }\end{array}$ & 397.497 & 451.956 & -93.324 \\
\hline $\begin{array}{c}\text { industria } \\
\text { I product }\end{array}$ & 2599.620 & 401.255 & -70.039 \\
\hline
\end{tabular}

Data source: customs statistics of Burma

\section{B. Ruili-Muse economic cooperation zone}

Yunnan Province of China and Myanmar had planed crossborder economic cooperation zones: a Yangon to Kunming Economic Corridor, both sides of the valley of Ruilijiang in the range of 600 square kilometers (two sides each about 300 square kilometers), plans to establish four square kilometers of the center of cross-border cooperation between China and Myanmar. Compared with going into the Strait of Malacca through Guangzhou, and it can shrink track shipping mileage of more than 3000 kilometers through the China-Burma border economic cooperation zone.

\section{Development status of border trade in Yunnan and Myanmar}

Yunnan is one of biggest province in southwest border of china, with the completion of the China-ASEAN Free Trade Area, the development of economic of Yunnan and Myanmar is more and more closer and closer. since December 1988, the two sides developed border trade, trade volume of Burma bilateral growth quickly.

As shown in Table 2, Yunnan import and export volume of foreign trade is $\$ 29.62$ billion in 2014 , the volume of 2014 has increased by $17.1 \%$ compared with 2013 .

\footnotetext{
* Corresponding author
} 
TABLE II.

STATISTICAL TABLE OF THE TRADE VOLUME OF YUNNAN AND MYANMAR

(USD Billion )

\begin{tabular}{|c|c|c|l|}
\hline Year & $\begin{array}{l}\text { Total import } \\
\text { and export of } \\
\text { Yunnan }\end{array}$ & $\begin{array}{l}\text { Total import and } \\
\text { export volume of } \\
\text { Yunnan to Burma }\end{array}$ & $\begin{array}{l}\text { Yunnan and } \\
\text { Myanmar trade } \\
\text { accounted for the } \\
\text { proportion of } \\
\text { imports and } \\
\text { exports of Yunnan }\end{array}$ \\
\hline 2010 & 133.68 & 17.59 & $13.16 \%$ \\
\hline 2011 & 160.53 & 20.72 & $12.91 \%$ \\
\hline 2012 & 210.05 & 22.72 & $10.82 \%$ \\
\hline 2013 & 258.29 & 41.73 & $16.16 \%$ \\
\hline
\end{tabular}

Data source: Kunming customs statistics

\section{CONSTRAINTS ON THE BORDER TRADE IN YUNNAN AND MYANMAR}

\section{A. Border settlement is not mature}

At present, Burma in the bank credit rating is still a high risk countries, Burma's national bank credit is generally low, anti risk ability is low. Some domestic banks had strict examination system in open a letter of credit or other payment.

Although some banks in Myanmar with some Chinese banks made a cooperation agreement open an account and allow exchanges between the two sides, however, because of the immaturity of the kyat exchange rate, and domestic war, there are obstacles in the implementation.

\section{B. The structure of border trade is not reasonable}

The main commodities of Yunnan exports to Myanmar include mechanical and electrical products, textiles and clothing, merchandise, imports from Myanmar mainly wood, metal ore, natural gas, jade; it can be seen from the import and export of goods, commodities trades between Yunnan and Myanmar focused in resource and labor-intensive industries, and a large proportion of these commodities.

Single commodity structure and import and export goods are mainly primary products, which reflects the low level of technical service,industrial development level is relatively backward and resulting in Burma's import and export structure is also relatively simple. Now the production of Yunnan from extensive type to intensive and technology type; the structure of the import and export trade has transferred to an high additional value commodity and higher technological content of service change, make the structure of foreign trade and economic cooperation more and more diversified.

\section{C. lack of development in logistics supplying system}

The Dehong in Yunnan Province, though already have lots of the good conditions for the development of modern logistics industry, there are still many aspects of the development requirements of modern logistics is not coordinated, such as: some traditional methods of management, operation mechanism, forms of organization and so on. These not harmonious mainly displays in, Firstly: from the point of view of the whole province, the lack of a complete and Unified overall planning; secondly: the overall scale of province is not large, competitiveness is not strong. Finally, there are the phenomenon of redundant construction, which resulted in the serious waste of social resources. Now the logistics industry is mainly administrative departments, serious fragmentation, which makes the logistics system of internal relations is artificially divided, seriously hindered the rational and efficient allocation of resources of logistics system.In the service and management level, the quality of the construction of the information platform and other facilities as well as practitioners is far from meet the requirements of modern logistics, the content of the service are still limited in many of the basic business, like warehousing, transportation and so on.for example: packaging, processing, distribution; these are not conducive to the development of high-level logistics service industry, also can not meet the personalized customer demand.

\section{The level of Customs declaration is not enough}

Customs exchange of China and Burma is not enough to make various types of documents, the format is not unified with Burma. Inconsistent form of documents will lead to the low efficiency of documents, review time, customs clearance and so on. Certificate of origin. Rules of origin is an important rule in the free trade agreement, if they do not meet the rules, you can not enjoy the corresponding preferential measures. Certificate of origin is a member of the preferential tariff products to enjoy the necessary documents, it can be proved that the import of products in line with the rules of origin.As a result, the format of certificate of origin has a great influence on the clearance of goods between China and Burma.

Although China has specialized customs institutions,in order to engage in business operations. Customs declaration professional degree has been greatly improved, but there are still some deficiencies. First, the proportion of professional customs clearance institutions is still too small, especially compared with other major trading countries. Secondly, the individual operating system is not reasonable. With the economic globalization and the development of science and technology, more and more varieties of goods. Therefore requires a more standardized, more stringent customs declaration system. While the individual operation error rate is high, so the need for professional customs agencies, can reduce the workload of the customs, improve the efficiency of customs clearance.

\section{Suggestions on Promoting the DeVElopment of BORDER TRADE IN YUNNAN AND MYANMAR}

\section{A. To speed up the process of cross-border settlement}

To explore the establishment of the port of currency circulation, enhance the level of cross-border financial cooperation. In order to build a Trinity of the border region currency exchange system, provide a good currency exchange market for actively promoting $\mathrm{RMB}$ regionalization, crossborder financial cooperation and the trade facilitation of ChinaBurmat. Actively explore to establish the policy guarantee, currency trading center platform, steadily Ruili-Myanmar currency exchange center of the transformation upgrade, improve index formation mechanism of the currency exchange, support finance square, and Longchuan County Financial Park . 


\section{B. Promote the transformation of commodity structure}

Yunnan should continue to implement the strategy of science and technology to promote the development of border trade, the further development of Yunnan Province

Exports of industrial advantages, such as mechanical and electrical products, phosphorus chemical industry, textiles and clothing and so on, and develop great potential for development of tea, tobacco and other products of export vigorously, increase and expand new export commodity exports, such as jade, Yunnan Baiyao, and constantly improve the quality of the traditional advantage of export commodities and added value, maintain the status of the product advantages, and a greater degree of Yunnan export advantage.

On the other hand, for the high technology content, environmental technology and good business, to increase its investment. Yunnan and Myanmar import and export commodities trade development to continuously improve the competitiveness of the goods themselves, expanding commodity in Burma market share, the commodity structure has changed, so that the external merchandise trade between Yunnan and Burma get rapid development.

Pay attention to the relationship between the industrial structure and export commodity structure, and make use of the change of the commodity structure.Impelled the Yunnan industrial structure to transfer, make use of senior and international of industrial structure to promote upgrading of export structure, and promote to integration of trade and industry,make own advantage products, commodity brand effect.

\section{Speed up the facilitation of customs clearance Logistics}

Make the strength of large-scale logistics enterprises as the leading, combine the modern logistics information, logistics facilities modernization, and logistics system integration, will be further integration of logistics resources, eventually forming perfect logistics enterprises to cultivate mechanism, vigorously develop the third party logistics enterprise, while speeding up the reform and reorganization of logistics enterprise benefit is not good.

Through continuous cultivation and transformation, a collection of resources in the province build a batch of real strong logistics enterprise, then by these strong logistics enterprises under the guidance of the government formed a perfect logistics system, not only can better sharing information, can also strengthen the logistics and the neighboring countries of exchange. In this regard to introduction of relevant policy support key logistics enterprises in Yunnan Province on the excellent logistics resources integration and further optimization allocation of resources, improve the operational efficiency of resources, speed up the building of our province modern logistics industry leading enterprises, and constantly improve our province logistics group competition strength.

Combination of channels and port construction, vigorously develop the port trade logistics, Southeast Asia, South Asia and other international and regional logistics market development, set up international logistics center in Dehong, with large clearance items, distribution processing, transportation of goods, commodity inspection, customs and other supporting functions, build integration office at the port of destination; transformation of key development of processing trade area or storage and transportation center, international logistics center, expanding transit, transit and processing trade import and export volume.establish logistics nodes and partnership in neighboring countries, make regional cooperation as the foundation of the regional logistics alliance, in consultation with the Southeast Asia and South Asia countries, establish international and regional green channel, safeguard international big channel along the region of import and export commodities unimpeded, to achieve barrier free international logistics.

\section{Improve the efficiency of customs clearance}

Legal system is a fundamental problem, only to improve the legal system of foreign trade, in order to establish a free trade. Complete and normative foreign trade law, the efficiency of the customs clearance is high and no loopholes can be drilled; open foreign trade law, making social supervision direction is conducive to the complete; coordination of port management system, customs, inspection and quarantine, ports, taxation, foreign exchange and other departments have unified and efficient management practices.

Implementation of paperless electronic customs clearance can solve the problem of slow clearance of paper documents, duplication of audit. Through the network management, can implement resource sharing, mutual supervision, not only can improve the efficiency of customs clearance, also can prevent false documents, smuggling evasions and so on.

Only to increase transparency, can achieve democracy. Realize transparent legislative procedure, subject to public comment, increase trader and especially trade of small business operators can be forecast and avoid charging without the authorization and non symmetrical fees; use the international standards and practices to streamline customs procedures as much as possible, formulate unified customs file format, refer to the format of the other international organizations such as EU the norms, UN dangerous goods declaration, UNCTAD GSP certificate of international customs organizations of the certificate of origin and the International Maritime Organization of the standard bill of lading and so on.

\section{CONCLUSION}

The main trade pattern is border trade between Yunnan and Burma. With the international environment changing and the needs of economic development among countries, So this paper promote three aspects to improve trade between Yunnan and Burma: Trade facilitation of custom, logistics facilitation, convenience of capital settlement. Better to serve the economics of the Yunnan province and Burma, make enterprises and people enjoy the frontier.

\section{ACKNOWLEDGMENT}

I would like to express my gratitude to all those who helped me during the writing of paper. Thanks for the help of my tutor, Ms. Zhang Lili, who has offered me suggestions in the academic studies. Second, I would like to express my gratitude to all the teachers on International Business School of YUFE, from whose devoted teaching and enlightening lectures I have 
benefited a lot and academically prepared for the paper.I should finally like to express my gratitude to my beloved parents

\section{REFERENCES}

[1] C.L. Li, and W.D. Zhu, "Facilitation of customs clearance and the development of China ASEAN Free Trade Area -- a case study of Yunnan Province," Around Southeast Asia, 2010, pp. 37-43.
[2] G.H. Yang, and X. Sun, "RMB settlement of cross-border trade and construction of regional cross-border RMB financial service center in Kunming," Inquiry into economic issues, 2011, pp. 133-138.

[3] B. Xiong, and H.X. Yan, "The analysis of Yunnan and SAARC countries trade competitiveness and complementarity," South East Asian Studies, 2012, pp. 46-53.

[4] J. Ren, "Economic cooperation and the construction of economic corridor in the area of Bangladesh and Burma," South East Asian Studies, 2014, pp. 56-63. 